\title{
Locally Advanced Malignant Solid Neoplasm
}

National Cancer Institute

\section{Source}

National Cancer Institute. Locally Advanced Malignant Solid Neoplasm. NCI Thesaurus.

Code C133093.

A malignant solid neoplasm that has spread from its original site of growth to nearby tissues or lymph nodes. 